\title{
Questions and answers in EBD Volume 17
}

\author{
Derek Richards \\ Editor, Evidence-based Dentistry
}

As in previous years we are highlighting the guidelines, questions and answers addressed by summaries in Evidence-based Dentistry. Evidence levels are only given for those papers achieving level $3 \mathrm{~A}$ and above.

Evidence-Based Dentistry (2015) 17, 123-126. doi:10.1038/sj.ebd.6401209

Guideline

\begin{tabular}{|l|l|l|l|}
\hline Topic & Title & Page & \\
\hline Caries & Guidance for management of early caries lesions in children and young adults: an EAPD policy document & $35-37$
\end{tabular}

Summaries

\begin{tabular}{|c|c|c|c|c|}
\hline Topic & Question & Answer & $\begin{array}{l}\text { Evidence } \\
\text { level }\end{array}$ & Page \\
\hline \multicolumn{5}{|l|}{ Caries } \\
\hline & $\begin{array}{l}\text { What are the benefits of cavity lining } \\
\text { in primary teeth? }\end{array}$ & $\begin{array}{l}\text { Current evidence does not support strong recommendations to use or } \\
\text { not to use liners after caries removal and before restoring cavities. }\end{array}$ & $1 \mathrm{~A}$ & $17-18$ \\
\hline & $\begin{array}{l}\text { Is the visual method accurate for } \\
\text { detecting caries in teeth? }\end{array}$ & $\begin{array}{l}\text { Visual caries detection method has good overall performance, although } \\
\text { the studies had high heterogeneity and risk of bias. The use of detailed and } \\
\text { validated indices seems to improve the accuracy of the method. }\end{array}$ & $1 \mathrm{~A}$ & $41-42$ \\
\hline & $\begin{array}{l}\text { How accurate are dental radiographs } \\
\text { for caries detection? }\end{array}$ & $\begin{array}{l}\text { Caries detection by dental radiographs is highly accurate for proximal } \\
\text { lesions and dentine caries lesions. For initial carious lesions the test } \\
\text { needs to be used with other more sensitive methods in populations that } \\
\text { present with high caries risk. }\end{array}$ & $1 \mathrm{~A}$ & 43 \\
\hline & $\begin{array}{l}\text { Is there sufficient clinical evidence } \\
\text { available to support the use of Tooth } \\
\text { Mousse } \AA(\text { MI Paste } ®) \text { and Tooth } \\
\text { Mousse Plus } ®(\text { MI Paste Plus } ®) \text { over } \\
\text { a routine oral care regimen for the } \\
\text { prevention and treatment of early } \\
\text { dental caries? }\end{array}$ & $\begin{array}{l}\text { There is insufficient evidence to support the clinical effectiveness of Tooth } \\
\text { Mousse } ₫ \text { and Tooth Mousse Plus } ₫ \text { over routine use of fluoride. The use } \\
\text { of the traditional preventive measures supported by high quality clinical } \\
\text { evidence, eg topical fluoride and fissure sealants, should continue. }\end{array}$ & $1 \mathrm{~A}$ & $46-47$ \\
\hline & $\begin{array}{l}\text { What is the effectiveness of fissure } \\
\text { sealants compared with fluoride } \\
\text { varnishes, or fissure sealants together } \\
\text { with fluoride varnishes compared } \\
\text { with fluoride varnishes alone, for } \\
\text { preventing dental caries? }\end{array}$ & $\begin{array}{l}\text { We found some low quality evidence suggesting the superiority of resin- } \\
\text { based fissure sealants over fluoride varnish applications for preventing } \\
\text { occlusal caries in permanent molars, and other low-quality evidence } \\
\text { for benefits of resin-based sealant and fluoride varnish over fluoride } \\
\text { varnish alone. Regarding glass ionomer sealant versus fluoride varnish } \\
\text { comparisons, we assessed the quality of the evidence as very low and } \\
\text { could draw no conclusions. }\end{array}$ & $1 \mathrm{~A}$ & $77-78$ \\
\hline & $\begin{array}{l}\text { What is the clinical efficacy and } \\
\text { the patient's comfort with Carisolv } \\
\text { compared to the traditional 'drilling } \\
\text { technique' for caries removal in the } \\
\text { primary dentition? }\end{array}$ & $\begin{array}{l}\text { The clinical efficacy of Carisolv seems as reliable as } \\
\text { with rotary instruments. However, the results should be interpreted } \\
\text { cautiously due to the heterogeneity among study designs and to the } \\
\text { shortage of available data. }\end{array}$ & $2 \mathrm{~A}$ & $44-45$ \\
\hline & $\begin{array}{l}\text { Does toothbrushing frequently } \\
\text { reduce caries? }\end{array}$ & $\begin{array}{l}\text { Individuals who state that they brush their teeth infrequently are at } \\
\text { greater risk for the incidence or increment of new carious lesions than } \\
\text { those brushing more frequently. }\end{array}$ & $2 \mathrm{~A}$ & 98-99 \\
\hline & $\begin{array}{l}\text { Is breastfeeding associated with } \\
\text { dental caries? }\end{array}$ & $\begin{array}{l}\text { Breastfeeding up to } 12 \text { months of age is not associated with an increased } \\
\text { risk of dental caries and in fact may offer some protection compared } \\
\text { with formula. However, children breastfed beyond } 12 \text { months had an } \\
\text { increased risk of dental caries. This may be due to other factors which are } \\
\text { linked with prolonged breastfeeding. }\end{array}$ & $3 \mathrm{~A}$ & $75-76$ \\
\hline \multicolumn{5}{|c|}{ Endodontics } \\
\hline & $\begin{array}{l}\text { Do antibiotics used preoperatively } \\
\text { reduce tooth pain associated with } \\
\text { irreversible pulpitis? }\end{array}$ & $\begin{array}{l}\text { Antibiotics given preoperatively (before definitive root canal therapy) } \\
\text { do not appearto significantly reduce toothache caused by irreversible } \\
\text { pulpitis. }\end{array}$ & 1B & $81-82$ \\
\hline & $\begin{array}{l}\text { How precise are electronic apex } \\
\text { locators in identifying the apical } \\
\text { constriction? }\end{array}$ & $\begin{array}{l}\text { The precision of electronic working length measurement depends on the } \\
\text { device used and the type of irrigation and is not influenced by the status } \\
\text { of the pulp tissue. }\end{array}$ & $2 \mathrm{~A}$ & $86-87$ \\
\hline
\end{tabular}




\begin{tabular}{|c|c|c|c|}
\hline $\begin{array}{l}\text { Does the use of magnification } \\
\text { devices in endodontic treatment } \\
\text { increaseoutcome success? }\end{array}$ & $\begin{array}{l}\text { It is unknown if andhow the type of magnification device affects the } \\
\text { treatment outcome considering large number of factors that may have a } \\
\text { significantimpact on the success of endodontic therapy. }\end{array}$ & N/A & $84-85$ \\
\hline \multicolumn{4}{|l|}{ Erosion } \\
\hline $\begin{array}{l}\text { What is the influence of diet on tooth } \\
\text { erosion? }\end{array}$ & $\begin{array}{l}\text { The evidence indicates that some dietary habits (soft drinks, acidic snacks/ } \\
\text { sweets and acidic fruit juices) increased the odds for erosion occurrence, while } \\
\text { milk or yogurt produced a protective effect. Methodological issues partly } \\
\text { explain the heterogeneity of the data for some dietary products. }\end{array}$ & N/A & 40 \\
\hline \multicolumn{4}{|l|}{ Hypersensitivity } \\
\hline $\begin{array}{l}\text { In adults are desensitising } \\
\text { toothpastes effective for dentine } \\
\text { hypersensitivity compared with } \\
\text { placebo? }\end{array}$ & $\begin{array}{l}\text { The review found sufficient evidence to support the use of potassium-, } \\
\text { stannous fluoride-, calcium sodium phosphosilicate- and arginine- } \\
\text { containing desensitising toothpaste for dentine hypersensitivity. It } \\
\text { found no significant desensitising effect difference between strontium- } \\
\text { containing toothpaste and placebo. }\end{array}$ & $1 \mathrm{~A}$ & $10-11$ \\
\hline $\begin{array}{l}\text { Is Calcium Sodium Phosphosilicate } \\
\text { (CSPS) effective in reducing dentine } \\
\text { hypersensitivity pain response? }\end{array}$ & $\begin{array}{l}\text { Despite the statistically significant results provided by the meta-analysis, } \\
\text { the clinical applicability remains uncertain. }\end{array}$ & $2 A$ & $12-13$ \\
\hline \multicolumn{4}{|l|}{ Implants } \\
\hline $\begin{array}{l}\text { In the posterior jaw do short implants } \\
\text { survive as long as standard implants? }\end{array}$ & $\begin{array}{l}\text { Short implants with lengths }<8 \mathrm{~mm}(4.0-7.0 \mathrm{~mm}) \text { should be used with } \\
\text { caution in the posterior jaw because the survival rates are reduced } \\
\text { significantly when compared to standard implants. }\end{array}$ & $1 \mathrm{~A}$ & $115-116$ \\
\hline $\begin{array}{l}\text { In patients having implants placed, } \\
\text { are smokers at higher risk for implant } \\
\text { failure, postoperative infection and } \\
\text { greater marginal bone loss? }\end{array}$ & $\begin{array}{l}\text { The insertion of implants in smokers affected the failure rates, the risk of } \\
\text { postoperative infections, as well as the marginal bone loss. The results } \\
\text { should be interpreted with caution due to the presence of uncontrolled } \\
\text { confounding factors in the included studies. }\end{array}$ & $2 \mathrm{~A}$ & $4-5$ \\
\hline $\begin{array}{l}\text { Is there a difference in marginal } \\
\text { bone loss or implant failure rates } \\
\text { between smokers and non-smokers, } \\
\text { depending on the follow-up period? }\end{array}$ & $\begin{array}{l}\text { The risk of marginal bone loss and implant failure is increased in smokers } \\
\text { compared to non-smokers, however the results should be interpreted } \\
\text { with caution since the data from the review are provided by retrospective } \\
\text { and cohort studies. }\end{array}$ & $2 \mathrm{~A}$ & $6-7$ \\
\hline \multicolumn{4}{|l|}{ Oral Cancer } \\
\hline $\begin{array}{l}\text { Is there an association between } \\
\text { mouthwash use and head and neck } \\
\text { cancer? }\end{array}$ & $\begin{array}{l}\text { This study adds to the evidence identified by recent large studies that } \\
\text { support this tendency for increased risk of head and neck cancer with } \\
\text { excessive, high frequency or prolonged use of mouthwash. }\end{array}$ & $3 \mathrm{~A}$ & $8-9$ \\
\hline \multicolumn{4}{|l|}{ Oral Health } \\
\hline $\begin{array}{l}\text { Is oral health promotion within } \\
\text { dental practice effective and how can } \\
\text { its effects be optimised? }\end{array}$ & $\begin{array}{l}\text { The results of this review suggest that the psychology of behaviour } \\
\text { change is the key to oral health promotion, and greater emphasis on } \\
\text { teaching oral health professionals about health psychology would make } \\
\text { oral health promotion in the dental surgery more effective. }\end{array}$ & $1 \mathrm{~A}$ & $70-71$ \\
\hline $\begin{array}{l}\text { What is the association between } \\
\text { smoking and tooth loss? }\end{array}$ & $\begin{array}{l}\text { There is a strong dose-dependent association between cigarette smoking } \\
\text { and the risk of tooth loss. The risk declines after cessation of cigarette } \\
\text { smoking; however, the risk may remain elevated for up to } 20 \text { years } \\
\text { compared with never smokers. Efforts to improve the oral health of } \\
\text { the population should include the prevention of smoking as well the } \\
\text { promotion of smoking cessation. }\end{array}$ & $2 \mathrm{~B}$ & $73-74$ \\
\hline $\begin{array}{l}\text { What are the associations between } \\
\text { psychosocial factors and oral hygiene } \\
\text { behaviour among people aged } 9 \text { to } \\
19 ?\end{array}$ & $\begin{array}{l}\text { Existing chairside and community oral health promotion interventions } \\
\text { for adolescents rarely target the psychosocial factors discussed in this } \\
\text { study, such as 'intention', 'social influences' and 'self- efficacy'. The review } \\
\text { highlights the current paucities in the literature and the need for further } \\
\text { research to develop and evaluate new interventions to improve oral health } \\
\text { based on behaviour change theory. }\end{array}$ & N/A & 72 \\
\hline \multicolumn{4}{|l|}{ Oral Medicine } \\
\hline $\begin{array}{l}\text { Does oral cryotherapy prevent oral } \\
\text { mucositis in patients with cancer who } \\
\text { are receiving treatment? }\end{array}$ & $\begin{array}{l}\text { There is confidence that oral cryotherapy leads to a large reduction in } \\
\text { oral mucositis in adults treated with 5FU. Although there is less certainty } \\
\text { on the size of the reduction on patients treated with melphalan, it is } \\
\text { certain there is reduction of severe mucositis. }\end{array}$ & $1 \mathrm{~A}$ & 80 \\
\hline $\begin{array}{l}\text { Does taking single dose oral } \\
\text { analgesics cause any adverse events? }\end{array}$ & $\begin{array}{l}\text { For most NSAIDs, paracetamol (acetaminophen), and combinations not } \\
\text { containing opioids, the rates of adverse events were similar to that of } \\
\text { placebos. However, for higher dosages, like } 1000 \mathrm{mg} \text { aspirin, } 1000 \mathrm{mg} \\
\text { diflunisal, and opioids or drug combinations containing opioids, there } \\
\text { was a statistically significant difference in the incidence of adverse events } \\
\text { reported (NNH 7.7( } 95 \% \mathrm{Cl} ; 4.8-20) \text { for } 1000 \mathrm{mg} \text { aspirin; } 7.5(95 \% \mathrm{Cl} ; \\
4.8-17) \text { for } 1000 \mathrm{mg} \text { diflunisal; } 3.5-8.6 \text { for opioids and combinations). } \\
\text { Serious adverse events were rare, occurring at about } 1 \text { in } 3,200 \text {. }\end{array}$ & $1 \mathrm{~A}$ & 83 \\
\hline $\begin{array}{l}\text { Is topical tacrolimus or clobetasol } \\
\text { effective in treatment of oral lichen } \\
\text { planus (OLP)? }\end{array}$ & $\begin{array}{l}\text { The authors concluded that using clobetasol or tacrolimus increases the } \\
\text { odds of improvement of OLP lesions and therefore they are effective } \\
\text { treatment for the condition, and go on to recommend tacrolimus as } \\
\text { first-line therapy. Currently tacrolimus is } 50 \text { times more expensive than } \\
\text { clobetasol, therefore cost of treatment should be taken into consideration. }\end{array}$ & $2 \mathrm{~A}$ & 16 \\
\hline
\end{tabular}


In patients treated with Antiresorptive Drugs (ARD), what is the occurrence rate and what are the risk indicators of Medication-Related Osteonecrosis of the Jaw (MRONJ) after dental extraction?

What is the efficacy and tolerability of parasympathomimetic drugs in the treatment of radiation-induced salivary gland dysfunction?
There is insufficient evidence to conclude the optimal surgical protocol for patients under ARD to prevent MRONJ. It seems reasonable to continue reinforcing the importance of preventive care for this target group of patients from the very beginning of treatment with ARD.

There is limited evidence to support the use of pilocarpine hydrochloride in the treatment of radiation-induced xerostomia. Currently, there is little evidence to support the use of other parasympathomimetic drugs in the treatment of radiation-induced xerostomia.

\section{Oral Surgery}

Is the submucosal injection of dexamethasone effective at controlling post- operative signs and symptoms following impacted third molar surgery?

What is the efficacy of single dose oral analgesics in adults with at least moderate pain following surgery?

Is hilotheraphy better than traditional ice cooling treatment in controlling short-term postoperative pain, oedem and functional limitations in patients undergoing surgical interventions in the maxillofacial region?
The review found moderate quality evidence that submucosal injections of dexamethasone reduced post-operative oedema and pain compared to a placebo following impacted third molar surgery. There was no significant difference in regards to trismus.

The authors conclude that there is a great amount of quality information on single dose analgesics, and highlighted the potential benefit of fastacting formulations and fixed formulations to achieve good long-lasting analgesia.

\section{The evidence supports the use of hilotherapy to reduce post-operative} pain and swelling in patients undergoing more complicated orofacial surgeries.

$2 B$

$14-15$

$58-59$

\section{Orthodontics}

Are removable functional appliances (RFAs) effective in correcting Class II malocclusions?

In orthodontic patients, what are the treatment effects of lingual compared to labial fixed appliances?

What is the best method for maintaining the correct position of teeth after orthodontic treatment?

Are fixed functional appliances as effective as removable functional appliances in correcting Class II malocclusions?

Is orthodontic treatment under 11 years of age effective?

What are the success rates of selfdrilling and self-tapping mini-screws in orthodontic treatment?

In orthodontic patients, what are the prognostic factors affecting the success rates of mini-screw implants inserted into the buccal posterior region?

What is the effect of three retention strategies on orthodontic relapse?

After five years or more out of retention, the three retention methods

Evidence indicates that RFAs are effective in improving Class II malocclusions in the short term. While the skeletal changes are minimal, significant dentoalveolar retroclination of maxillary incisors and proclination of mandibular incisors and soft tissue changes occurred with RFAs.

Based on existing trials there is insufficient evidence to make robust recommendations for lingual fixed orthodontic appliances regarding their therapeutic or adverse effects, as the quality of evidence was low.

We did not find any evidence that wearing thermoplastic retainers full-time provides greater stability than wearing them part-time, but this was assessed in only a small number of participants. Overall, there is insufficient high quality evidence to make recommendations on retention procedures for stabilising tooth position after treatment with orthodontic braces. Further high quality RCTs are needed.

There is low quality evidence from clinical trials that indicate removable functional appliances are as effective as fixed functional appliances in treating Class II malocclusions among growing children.

The results suggest a lack of evidence to prove that early treatment carries additional benefit over and above that achieved with treatment commencing later; however, this does not imply that early treatment is ineffective. The additional cost and burden to the patient, parent and clinician may, therefore, generally negate early treatment.

Because of the numerous limitations in this systematic review, we have no confidence that the success rates of self-drilling and self-tapping insertion techniques of orthodontic mini-implants are similar.

This meta-analysis based on non-randomised clinical studies showed that jaw of insertion, age, MI length and MI diameter are critical risk factors to the success of Mls, whereas sex was not influential. had achieved equally favourable clinical results. Thus a maxillary vacuum formed retainer (VFR) combined with a bonded canine-to-canine retainer in the mandible, a maxillary VFR combined with stripping of the mandibular anterior teeth and a prefabricated positioner can all be recommended.

\section{Patient Safety}

What tools are available to help improve patient safety in the dental setting?

The available literature on patient safety is in its infancy. Surgical checklists may be effective in reducing surgical errors.

$1 \mathrm{~A}$

$54-55$

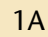

105

106

\section{Periodontal disease}

Should adults with chronic periodontitis have their treatment carried out within a 24-hour period?
From the 12 included trials there is no clear evidence that full-mouth scaling or full-mouth disinfection provide additional benefit compared to conventional scaling and root planing. In practice, the decision to select one approach over another should include patient preference and the convenience of the treatment schedule. 


\begin{tabular}{|c|c|c|c|c|}
\hline & $\begin{array}{l}\text { What is influence of systemic } \\
\text { antibiotics in the treatment of } \\
\text { aggressive periodontitis (AgP)? }\end{array}$ & $\begin{array}{l}\text { The results support a statistically significant benefit of adjunctive systemic } \\
\text { antibiotics in the treatment of AgP. }\end{array}$ & $1 \mathrm{~A}$ & 100 \\
\hline & $\begin{array}{l}\text { What are the characteristics of } \\
\text { currently published patient-based } \\
\text { tools or systems used to assess levels } \\
\text { of risk for periodontitis progression? } \\
\text { Are results from current patient- } \\
\text { based risk assessment tools predictive } \\
\text { of periodontitis progression in adults } \\
\text { treated for this disease? }\end{array}$ & $\begin{array}{l}\text { This systematic review provided a thorough approach to defining the } \\
\text { periodontal risk assessment tools that are available to the clinician. } \\
\text { Although any of these tools may be applied to clinical settings, there } \\
\text { is limited evidence as to their impact, long-term, on the efficacy } \\
\text { of assessing patient risk. Common sense allows for estimating risk } \\
\text { assessment based on tooth loss for patients. More detailed longitudinal } \\
\text { studies are needed for each of these tools to define which is most } \\
\text { applicable to the oral health professional. }\end{array}$ & $2 \mathrm{~A}$ & $19-20$ \\
\hline & $\begin{array}{l}\text { Does a patient's degree of } \\
\text { compliance with appointments } \\
\text { affect the risk of tooth loss during } \\
\text { supportive periodontal treatment? }\end{array}$ & $\begin{array}{l}\text { Tooth loss rate was significantly lower in the regular compliance } \\
\text { group over five years. To prevent one extraction, } 20 \text { teeth have to be } \\
\text { maintained with regular compliance for more than five years }\end{array}$ & $2 \mathrm{~A}$ & $21-22$ \\
\hline & $\begin{array}{l}\text { Are home-use anti-plaque agents } \\
\text { effective for managing gingivitis? }\end{array}$ & $\begin{array}{l}\text { The authors concluded that the use of chemical agents provided } \\
\text { statistically significant improvement in gingival bleeding and plaque } \\
\text { indices and the best results were achieved using mouthrinses. There is a } \\
\text { query regarding the clinical relevance of the findings. }\end{array}$ & $2 \mathrm{~A}$ & $48-49$ \\
\hline & $\begin{array}{l}\text { What type of preventive periodontal } \\
\text { programmes provide the best } \\
\text { outcomes in Down Syndrome } \\
\text { patients? }\end{array}$ & $\begin{array}{l}\text { Professional intervention and periodontal maintenance significantly } \\
\text { reduced plaque and gingival indices, irrespective of the treatment } \\
\text { performed. Increased frequency of interventions was associated with } \\
\text { better outcomes, especially in younger age groups. }\end{array}$ & N/A & $101-$ \\
\hline \multicolumn{5}{|c|}{ Radiography } \\
\hline & $\begin{array}{l}\text { Does preoperative use of cone beam } \\
\text { computed tomography compared } \\
\text { with panoramic radiography reduce } \\
\text { the risk of inferior alveolar nerve } \\
\text { damage? }\end{array}$ & $\begin{array}{l}\text { This RCT provides moderate quality evidence that CBCT imaging } \\
\text { provides no reduction in post-operative patient morbidity compared } \\
\text { to PR following third molar removal, despite the increased radiation } \\
\text { exposure and costs associated with CBCT. }\end{array}$ & 1B & $\begin{array}{l}117- \\
118\end{array}$ \\
\hline \multicolumn{5}{|c|}{ Restorative Dentistry } \\
\hline & $\begin{array}{l}\text { Does enamel bevelling affect the } \\
\text { retention of composite restorations in } \\
\text { noncarious cervical lesions? }\end{array}$ & $\begin{array}{l}\text { It could be concluded that there is no difference between bevelled and } \\
\text { non-bevelled technique over the short-term follow-up of } 12-18 \text { months. } \\
\text { This conclusion was based on only two low risk of bias RCTs. }\end{array}$ & $1 \mathrm{~A}$ & $88-89$ \\
\hline & $\begin{array}{l}\text { What is the effect of overloading } \\
\text { already osseointegrated dental } \\
\text { implants on marginal bone? }\end{array}$ & $\begin{array}{l}\text { The effect of implant overload on bone/implant loss in clinically well- } \\
\text { integrated implants is poorly reported and provides little unbiased } \\
\text { evidence to support a cause-and-effect relationship }\end{array}$ & $1 \mathrm{~A}$ & $92-93$ \\
\hline & $\begin{array}{l}\text { Is there an effect deriving from the } \\
\text { choice of implant treatment on } \\
\text { muscular activity when comparing } \\
\text { implant overdentures and implant- } \\
\text { retained fixed dental prostheses } \\
\text { (IRDP) to dentates and edentulous } \\
\text { during clenching and chewing? }\end{array}$ & $\begin{array}{l}\text { Overall, the main conclusion was that the muscular activation in } \\
\text { edentulous patients with IRDPs increased after rehabilitation with } \\
\text { implant-supported prostheses. }\end{array}$ & $1 \mathrm{~A}$ & $\begin{array}{l}119- \\
120\end{array}$ \\
\hline & $\begin{array}{l}\text { What are the effects of removable } \\
\text { dental prostheses on masticatory } \\
\text { performance in patients with a } \\
\text { shortened dental arch? }\end{array}$ & $\begin{array}{l}\text { This systematic review illustrates the paucity of high quality evidence to } \\
\text { answer this research question. }\end{array}$ & $2 A$ & 116 \\
\hline & $\begin{array}{l}\text { What are the effects of restoration of } \\
\text { endodontically treated teeth (with } \\
\text { or without post and core) by crowns } \\
\text { versus conventional filling materials? }\end{array}$ & $\begin{array}{l}\text { Insufficient evidence exists to assess the effects of crowns compared to } \\
\text { conventional fillings for the restoration of root-filled teeth. Until more } \\
\text { evidence is available, clinicians should continue to base decisions about how } \\
\text { to restore root-filled teeth on their own clinical experience, whilst taking into } \\
\text { consideration the individual circumstances and preferences of their patients. }\end{array}$ & $2 \mathrm{~B}$ & $50-51$ \\
\hline & $\begin{array}{l}\text { In edentulous adult patients, } \\
\text { what is the effectiveness of all-on- } \\
\text { four treatment concept in terms } \\
\text { of implant survival, fixed dental } \\
\text { prosthesis (FDP) survival and bone } \\
\text { level changes? }\end{array}$ & $\begin{array}{l}\text { Current evidence suggests that the all-on-four treatment concept may } \\
\text { be a promising approach for the oral rehabilitation of the edentulous } \\
\text { jaw. However, the lack of good quality long-term studies makes the all- } \\
\text { on-four concept still experimental. As such, clinicians and patients must } \\
\text { consider this caveat in their clinical decision-making process. }\end{array}$ & N/A & $56-57$ \\
\hline & $\begin{array}{l}\text { What is the longevity of anterior } \\
\text { composite restorations? } \\
\text { What is the clinical effectiveness } \\
\text { (durability and longevity) of anterior } \\
\text { composite restorations? }\end{array}$ & $\begin{array}{l}\text { Despite the limitations of both reviews, they generally conclude } \\
\text { that anterior composite restorations typically perform comparably } \\
\text { to posterior composite resins in the short-to-moderate time frame. }\end{array}$ & N/A & $90-91$ \\
\hline \multicolumn{5}{|c|}{ Smoking } \\
\hline & $\begin{array}{l}\text { What is the cytotoxicity and } \\
\text { genotoxicity of short- and long-term } \\
\text { e-cigarette vapour exposure on a } \\
\text { panel of normal epithelial and head } \\
\text { and neck squamous cell carcinoma } \\
\text { (HNSCC) cell lines? }\end{array}$ & $\begin{array}{l}\text { E-cigarette vapour is not inert and exposure can lead to cytotoxic and } \\
\text { DNA damaging effects in vitro. Epithelial cells can survive in e-cigarette } \\
\text { vapour extract for eight weeks but only } 24 \text { hours when exposed to } \\
\text { cigarette smoke extract. }\end{array}$ & N/A & $2-3$ \\
\hline \multicolumn{5}{|c|}{ Temporomandibular Disorders } \\
\hline & $\begin{array}{l}\text { Are manual therapies (MT) an } \\
\text { effective treatment for patients with } \\
\text { temporomandibular disorders? }\end{array}$ & $\begin{array}{l}\text { There is widely varying evidence that MT improves pain, MMO and PPT } \\
\text { in subjects with TMD signs and symptoms, depending on the technique. } \\
\text { Further studies should consider using standardised evaluations and } \\
\text { better study designs to strengthen clinical relevance. }\end{array}$ & $2 \mathrm{~A}$ & $25-26$ \\
\hline
\end{tabular}

